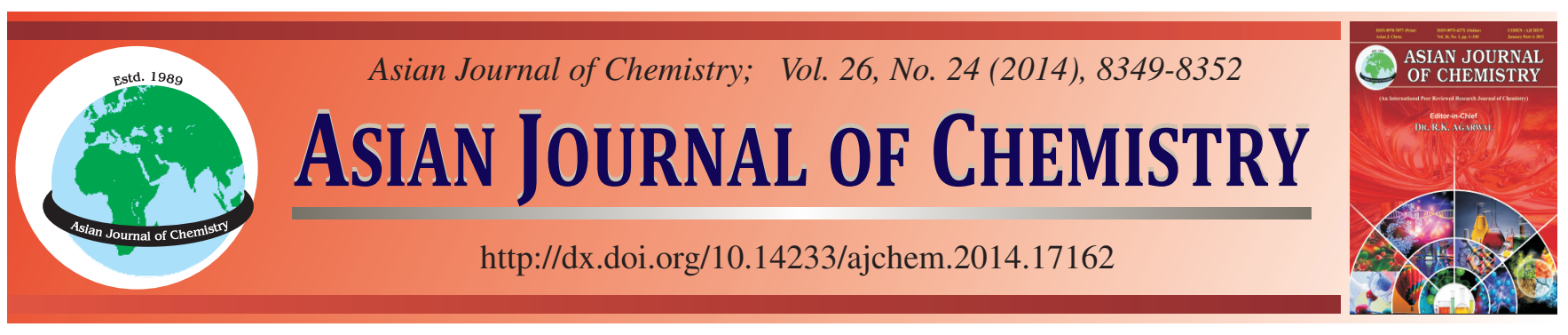

\title{
Determination of Benzo(a)pyrene in Surface Water of Shatt Al-Hilla River, Iraq
}

\author{
FAlah H. Hussein ${ }^{1, *}$, FAIQ F. KARAM ${ }^{2}$ and SAdiQ J. BaQIR ${ }^{1}$
}

${ }^{1}$ Chemistry Department, College of Science, University of Babylon, Hilla, Iraq

${ }^{2}$ Chemistry Department, College of Science, University of Al-Qadisiya, Al Diwaniyah, Iraq

*Corresponding author: Tel: + 964 7804009236, E-mail: abohasan_hilla@yahoo.com

\begin{abstract}
In this work, the concentrations of benzo(a)pyrene in surface water of Shatt Al-Hilla river of Iraq were monitored for one year, starting from November 2011 to October 2012. The process was done by solid phase extraction and HPLC technique with UV-visible detector. Water samples were taken from 14 sites, these sites are selected according to the human activity which present on both banks of the Shatt Al-Hilla river. They showed high spatial variations in concentrations of benzo(a)pyrene from site to site. The highest concentration was $601.81 \mathrm{ppb}$ in site six in November 2011, while in other sites were no detection for this compound. The accumulation concentration of benzo(a)pyrene in all sites during the study period was $871.69 \mathrm{ppb}$. In May 2012 the most appearance for this compound (eight sites of fourteen), while in months of December 2011, February 2012 and August 2012 were the lowest number of polluted sites (one site) for everyone.
\end{abstract}

Keywords: Surface waters, Benzo(a)pyrene, HPLC, Shatt Al-Hilla, Iraq.

\section{INTRODUCTION}

Polycyclic aromatic hydrocarbons refer to hydrocarbons containing of two or more fused aromatic rings. All polycyclic aromatic hydrocarbons are neutral and non polar and they have high stability. They have high melting points and low vapor pressures and low water solubility. Generally the solubility and volatility of polycyclic aromatic hydrocarbons decrease and hydrophobicity increase with an increasing in the number of fused aromatic rings ${ }^{1}$. These compounds can be produced by the smoke of fires and agriculture fires, metal processing facilities, fossil fuels burning, coke oven, etc. The continuous delocalization of $\pi$ electron made of these compounds exhibit a low water solubility and high stability and that leading to their accumulation in food chains ${ }^{2}$. Several foundations are listed polycyclic aromatic hydrocarbons as pollutant because of their mutagenic and carcinogenic properties ${ }^{3-5}$. In order to protect public health, the European Community (EC) has regulated the presence of polycyclic aromatic hydrocarbons compounds in food. In this regulation, benzo[a]pyrene (BaP) was selected as a marker compound for the occurrence and effect of carcinogenic polycyclic aromatic hydrocarbons ${ }^{6}$. Benzo(a)pyrene, a five-ring polycyclic aromatic hydrocarbon, as other polycyclic aromatic hydrocarbons, is produced from the incomplete combustion of various biogenic or anthropogenic carbonaceous matters. It is an environmentally important chemical carcinogen compound that exerts its carcinogenic activity through metabolites which react with and modify proteins and nucleic acids. Mammals metabolize benzo(a)pyrene by enzymatic oxidation to phenols, epoxides, dihydrodiols and water-soluble conjugates, is a major DNA damaging compound found in tobacco smoke and an environmental contaminant ${ }^{7,8}$. In the lung, benzo(a)pyrene interacts with cytochrome p450 enzymes, producing benzo(a)pyrene-trans-7,8dihydrodiol-9,10-epoxide(anti)(+), this metabolite interacts with DNA to form adducts ${ }^{9}$. In order that protect public health, the European Community (EC) has regulated the existence of polycyclic aromatic hydrocarbons in food ${ }^{10}$. In this regulation, benzo(a)pyrene was selected as a marker for the occurrence and effect of carcinogenic polycyclic aromatic hydrocarbons.

There are different reports mention the application of solid phase extraction (SPE) for pre concentration of polycyclic aromatic hydrocarbons from water samples ${ }^{11-14}$. Solid phase extraction is offer the faster method compare with many traditional liquid-liquid extraction techniques ${ }^{15}$. Other advantages of solid phase extraction such as reduction in the amount of solvents used, possibility of automatically extraction (by online coupling with GC or HPLC) and simplicity of operation $^{16}$. Atmospheric deposition in surface water is considered to be an important input of polycyclic aromatic hydrocarbons ${ }^{17}$. Low molecular weight (LMW) of polycyclic aromatic hydrocarbons that consist of two and three rings are occur in the 
atmosphere in the vapor phase whereas the largest molecular weight (five rings) of polycyclic aromatic hydrocarbons are bound to particles. Intermediate molecular weight (four rings) of polycyclic aromatic hydrocarbon are partitioning between the particulate phases and vapor depending on the temperature of atmosphere ${ }^{18}$. Due to their trace level concentration in surface water, it is required efficient preconcentration method, high sensitive and selective method for separation and analysis techniques ${ }^{19}$. Several researchers were used different techniques to detect polycyclic aromatic hydrocarbon compounds e.g., high performance liquid chromatography-fluorescence detection $^{20,21}$ or ultraviolet diode-array detection ${ }^{22}$, gas chroma-

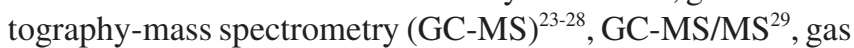
chromatography $(\mathrm{GC})^{30,31}$, high-pressure liquid chromatography with fluorescent and diode array detectors (HPLC-FLD/ DAD $)^{32}$ and high performance liquid chromatography coupled to electro spray ionization mass spectrometry ${ }^{33}$. Health effects resulting from exposure to high concentrations of polycyclic aromatic hydrocarbons have been discussed recently in the literature ${ }^{34,35}$. Seven polycyclic aromatic hydrocarbon compounds have been classified by the US-Environmental Protection Agency as compounds of problem human carcinogens $^{36}$ (USEPA, 1994). These are benzo(a)pyrene, benzo(a)anthracene, chrysene, benzo(k)fluoranthene, benzo(B)fluoranthene, dibenzo(a,h)anthracene and indeno(1,2,3-cd)pyrene. Benzo[a]pyrene $(\mathrm{BaP})$ structure is shown in Fig. 1.

This study aims to evaluate the level of contaminations in surface water samples with benzo(a)pyrene from selected sites in Shatt Al-Hilla river of Iraq.

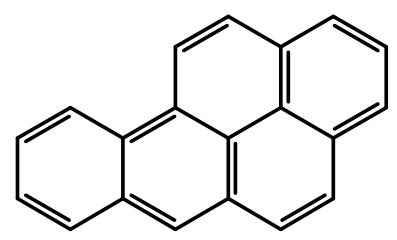

Fig. 1. Structure of benzo(a)pyrene

\section{EXPERIMENTAL}

The studied area was described in our previous work ${ }^{37}$. One hundred and sixty eight of water samples from Shatt AlHilla river were collected during period of study. These samples were placed in pre-cleaned Amber glass bottle $(2.5 \mathrm{~L})$ with screw cap and lined with foil and kept in cooler box with $4{ }^{\circ} \mathrm{C}$ to ensures wouldn't exposure to degradation when they expose to the light or high temperatures degree through transferring the samples to laboratory. After transfer the samples are kept in refrigerator.

The standard solution of benzo(a)pyrene was purchased from supelco. This standard was stored at $4{ }^{\circ} \mathrm{C}$. Solvents were used in this work such as acetonitrile and dichloromethane purchased from Sigma Aldrich. All chemicals were used without further purification.

Extraction procedure: All glassware's which used were pre cleaned and then dried for $1 \mathrm{~h}$ at $180^{\circ} \mathrm{C}$. The washing was done by using the following cleaning steps: washing acids, solvents, detergents, hot water, rinsed with distill water. Water samples were extracted using solid phase extraction method (SPE) by Supelco, Supelclean ${ }^{\mathrm{TM}}$ ENVI-18 SPE Tube bed wt. $500 \mathrm{mg}$, volume $6 \mathrm{~mL}$, pkg of 30 ea. These tubes were conditioned with following solvents to increase extraction efficiency: isopropanol, acetonitrile, dichloromethane, methanol, ethanol and distilled water before extraction process. After conditioning columns $1 \mathrm{~L}$ of water sample passes through filter paper and then passes through the extraction column with constant flow rate $2 \mathrm{~mL} / \mathrm{min}$. Suspended polycyclic aromatic hydrocarbons were eluted of extraction column using dichloromethane. The passed solution was concentrated to $1 \mathrm{~mL}$ by rotary evaporator. Extraction process was done within $24 \mathrm{~h}$ after sample collection.

HPLC conditions. After extraction process, a portion of extract, $(20 \mu \mathrm{L})$ was injected by micro syringe reversed-phase HPLC. The experimental parameters for HPLC Shimadzu LC10 AVP, polycyclic aromatic hydrocarbon column $250 \times 4.6$ $\mathrm{mm}$ I.d with guard column $5 \times 4.6 \mathrm{~mm} \mathrm{I.d}$, flow rate: $2 \mathrm{~mL} / \mathrm{min}$, detected by UV detector (absorbance at $254 \mathrm{~nm}$ ). Benzo(a)pyrene were eluted by water/acetonitrile gradient as shown in our previous work ${ }^{38}$.

\section{RESULTS AND DISCUSSION}

Bright and Healey ${ }^{39}$ found $65 \%$ of 4-6 ring polycyclic aromatic hydrocarbons in sludge's from a urban area, Vancouver (Canada). Crepineau et al..$^{40}$ concerning the contribution of motor traffic contamination to the atmosphere, data from literature are controversed. Fromme et al. in Berlin ${ }^{41}$ found a major emission of fluoranthene and pyrene from diesel engines. Lim et al. ${ }^{42}$ in the center of Birmingham UK, found 80-82 \% of 4-7 ring polycyclic aromatic hydrocarbons from traffic emissions to the urban air whereas they were only 61$67 \%$ in the background area. In contrast, Tsai et al. ${ }^{43}$, at a highway toll station of Northern Taiwan, reported a ratio of 47 ring polycyclic aromatic hydrocarbons of only $6.9 \%$.

The results exhibit high variety between the concentrations of benzo(a)pyrene from site to site and from month to month. The results in Table-1, illustrate the variation of benzo(a)pyrene concentration levels for twelve months from fourteen sites distributed on the length of Shatt Al-Hilla river. The maximum value of this compound was appear in site six /November 2011 it was $601.81 \mathrm{ppb}$ as shown in Fig. 2. This site as described in study area, the pollution source is the drain pipe of sewage came from Al-Wardiya region which discharge the contents throw river. The summation of benzo(a)pyrene in all sites for one year was $871.69 \mathrm{ppb}$.

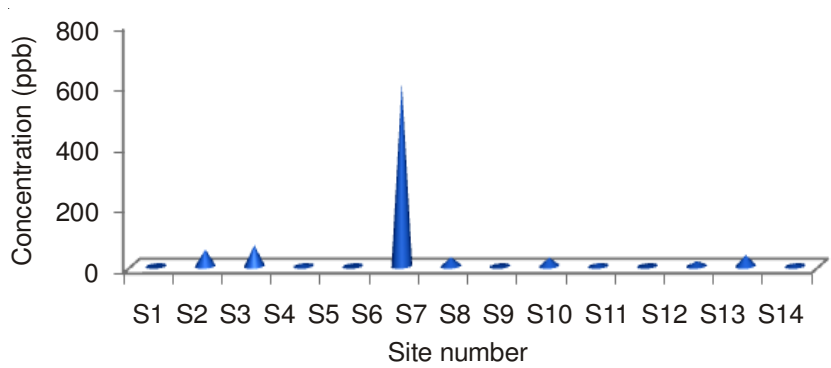

Fig. 2. Summations of benzo(a)pyrene distributed for every site 


\begin{tabular}{ccccccccccccc}
\hline \multicolumn{10}{c}{ TABLE-1 } \\
\multicolumn{10}{c}{ CONCENTRATIONS OF BENZO(a)PYRENE (NANOGRAMS PER LITER) FOR ONE YEAR (n = 3) IN SURFACE } \\
\multicolumn{1}{c}{ WATER FROM SHATT AL-HILLA RIVER DURING THE PERIOD, NOVEMBER 2011 TO OCTOBER 2012 } \\
\hline Site & Nov- & Dec- & Jan.- & Feb.- & Mar- & Apr- & May- & Jun- & Jol- & Aug.- & Sep.- & Oct.- \\
No. & 2011 & 2011 & 2012 & 2012 & 2012 & 2012 & 2012 & 2012 & 2012 & 2012 & 2012 & 2012 \\
\hline S1 & 0.00 & 0.00 & 0.00 & 0.00 & 0.00 & 0.00 & 0.00 & 0.00 & 0.00 & 0.00 & 0.00 & 0.00 \\
S2 & 54.7 & 0.00 & 0.00 & 0.00 & 0.00 & 0.09 & 0.00 & 0.00 & 0.00 & 0.00 & 0.00 & 0.00 \\
S3 & 65.47 & 0.00 & 0.00 & 0.00 & 0.00 & 0.00 & 2.74 & 0.23 & 0.00 & 0.00 & 0.00 & 0.00 \\
S4 & 4.17 & 0.00 & 0.00 & 0.00 & 0.00 & 0.00 & 0.00 & 0.00 & 0.00 & 0.00 & 0.09 & 0.00 \\
S5 & 0.00 & 0.00 & 0.00 & 4.01 & 0.37 & 0.00 & 0.00 & 0.67 & 0.00 & 0.00 & 0.00 & 0.00 \\
S6 & 601.81 & 0.00 & 0.00 & 0.00 & 0.00 & 0.00 & 0.23 & 0.00 & 0.01 & 0.00 & 0.00 & 0.00 \\
S7 & 29.28 & 0.00 & 0.00 & 0.00 & 0.00 & 0.09 & 0.01 & 0.00 & 0.00 & 0.00 & 0.00 & 0.01 \\
S8 & 0.00 & 0.00 & 3.46 & 0.00 & 0.00 & 0.00 & 0.51 & 0.00 & 0.09 & 0.00 & 0.00 & 0.00 \\
S9 & 27.76 & 0.00 & 0.00 & 0.00 & 0.00 & 0.00 & 0.00 & 0.00 & 0.00 & 0.00 & 0.00 & 0.00 \\
S10 & 0.00 & 0.00 & 0.00 & 0.00 & 3.37 & 0.00 & 6.36 & 0.00 & 0.22 & 0.23 & 0.00 & 0.02 \\
S11 & 0.00 & 0.00 & 0.00 & 0.00 & 0.00 & 0.00 & 4.26 & 0.00 & 0.00 & 0.00 & 0.00 & 0.00 \\
S12 & 0.00 & 0.00 & 0.63 & 0.00 & 14.25 & 0.00 & 1.44 & 0.00 & 0.00 & 0.00 & 0.00 & 0.00 \\
S13 & 0.00 & 0.00 & 0.00 & 0.00 & 3.46 & 0.00 & 33.13 & 0.00 & 0.00 & 0.00 & 0.21 & 0.00 \\
S14 & 0.00 & 7.98 & 0.00 & 0.00 & 0.33 & 0.00 & 0.00 & 0.00 & 0.00 & 0.00 & 0.00 & 0.00 \\
\hline
\end{tabular}

Sample analysis showed the presence of most benzo(a)pyrene pollutant in nearly all sampling stations. Concentrations of benzo(a)pyrene for all sites during study period are present in Table-2. Location of sampling station, average concentration values, summation of concentrations for every site during period of study and standard deviation are presented in Table2. High concentrations were measured for benzo(a)pyrene, was exceeded at sampling station six, while no detection of benzo(a)pyrene during period of study in site one. The most appearance of benzo(a)pyrene was in May 2012, eight sites in this month were regarded concentrations of benzo(a)pyrene. These sites are S3, S6, S7, S8, S10, S11, S12 and S13. The lowest appearance during one year were in months of December 2011, February 2012 and August 2012 in sites S14, S5 and S10, respectively. Site six is the most contaminated site with benzo(a)pyrene among fourteen, the average in this site was $50.17 \mathrm{ppb}$ during one year. The statistical result shows that the right bank of the river is more polluted than left bank

TABLE-2

\begin{tabular}{|c|c|c|c|c|c|}
\hline Site No. & Location & Average & Sumt & tion & STDEV \\
\hline S1 & $\mathrm{R}$ & 0.00 & & & 0.00 \\
\hline S2 & $\mathrm{R}$ & 4.56 & & & 15.78 \\
\hline S3 & $\mathrm{L}$ & 5.70 & & & 18.83 \\
\hline S4 & $\mathrm{R}$ & 0.68 & & & 1.58 \\
\hline S5 & $\mathrm{L}$ & 0.08 & & & 0.21 \\
\hline S6 & $\mathrm{R}$ & 50.17 & & & 173.72 \\
\hline S7 & $\mathrm{L}$ & 2.44 & & & 8.44 \\
\hline S8 & $\mathrm{L}$ & 0.33 & & & 0.99 \\
\hline S9 & $\mathrm{L}$ & 2.31 & & & 8.01 \\
\hline $\mathrm{S} 10$ & $\mathrm{~L}$ & 0.85 & & & 1.98 \\
\hline S11 & $\mathrm{L}$ & 0.35 & & & 1.22 \\
\hline $\mathrm{S} 12$ & $\mathrm{R}$ & 1.36 & & & 4.08 \\
\hline $\mathrm{S} 13$ & $\mathrm{~L}$ & 3.06 & & & 9.51 \\
\hline S14 & $\mathrm{R}$ & 0.69 & & & 2.29 \\
\hline & Summation & & $\begin{array}{c}\mathrm{L} \\
181.86\end{array}$ & $\begin{array}{c}\mathrm{R} \\
689.74 \\
871.69\end{array}$ & \\
\hline
\end{tabular}

(summation of right bank $=689.74$, while the summation of left bank $=181.86)$.

\section{Conclusion}

In the present study, the benzo(a)pyrene compound was chosen for its importance from an environmental point of view, being one of the most potent carcinogens among the polycyclic aromatic hydrocarbons. The highest concentration of benzo(a)pyrene was (601.81) ppb at site six in November 2012. The results showed spatial variations and monthly variations in concentrations of benzo(a)pyrene. The statistical result shows that the right bank of the river is more polluted than left bank (summation of Right bank $=689.74$, while the summation of left bank =181.86). The most appearance of benzo(a)pyrene was in May 2012, eight sites in this month were regarded pollution with this pollutant while the lowest appearance during one year were in months December 2011, February 2012 and August 2012.

\section{ACKNOWLEDGEMENTS}

The authors thank the Arab Scientist and Technologist Foundation (ASTF) for financial support.

\section{REFERENCES}

1. N. Vela, M. Martinez-Menchon, G. Navarro, G. Perez-Lucas and S. Navarro, J. Photochem. Photobiol. Chem., 232, 32 (2012).

2. J. Kou, Z. Li, Y. Yuan, H. Zhang, Y. Wang and Z. Zou, Environ. Sci. Technol., 43, 2919 (2009).

3. C. Dong, C. Chen and C. Chen, Int. J. Environ. Res., 9, 3085 (2012).

4. L. Sverdrup, T. Nielsen and P. Krogh, Environ. Sci. Technol., 36, 2429 (2002).

5. M. Qiao, C. Wang, S. Huang, D. Wang and Z. Wang, Environ. Int., 32, 28 (2006).

6. F. Lopez-Jimenez, A. Ballesteros-Gomez and S. Rubio, Food Chem., 143, 341 (2014).

7. Z. Wu, Y. Lin, H. Xu, H. Dai, M. Zhou, S. Tsao, L. Zheng and B. Shen, Mutat. Res., 731, 85 (2012).

8. X. Wu, H. Zhao, R. Suk and D. Christiani, Oncogene, 23, 6500 (2004).

9. E. Braithwaite, X. Wu and Z. Wang, Carcinogenesis, 19, 1239 (1998).

10. F. Lopez-Jimenez, A. Ballesteros-Gomez and S. Rubio, Food Chem., 143, 341 (2014).

11. W. Kanchanamayoon and N. Tatrahun, World J. Chem., 3, 51 (2008).

12. R. Doong, S. Chang and Y. Sun, J. Chromatogr. A, 879, 177 (2000).

13. E. Hagestuen, Talanta, 52, 727 (2000). 
14. N. Li and H.K. Lee, J. Chromatogr. A, 921, 255 (2001).

15. T. Oluseyi, K. Olayinka, B. Alo and R. Smith, African J. Environ. Sci. Technol., 5, 482 (2011).

16. E. Gilgenast, G. Boczkaj, A. Przyjazny and M. Kaminski, Anal. Bioanal. Chem., 401, 1059 (2011).

17. A. Nagy, G. Simon and I. Vass, Nova Biotechnol. Chim., 11, 27 (2012).

18. K. Srogi, Environ. Chem. Lett., 5, 169 (2007).

19. J. Ma, R. Xiao, J. Li, J. Yu, Y. Zhang and L. Chen, J. Chromatogr. A, 1217, 5462 (2010).

20. M. Garciafalcon, Food Chem., 90, 643 (2005).

21. M. Bourdat-Deschamps, J.-J. Daudin and E. Barriuso, J. Chromatogr. A, 1167, 143 (2007)

22. J.N. Brown and B.M. Peake, Anal. Chim. Acta, 486, 159 (2003).

23. K. Li, H. Li, L. Liu, Y. Hashi, T. Maeda and J.-M. Lin, J. Chromatogr. A, 1154, 74 (2007)

24. V. Fernandez-Gonzalez, E. Concha-Grana, S. Muniategui-Lorenzo, P. López-Mahía and D. Prada-Rodríguez, J. Chromatogr. A, 1196-1197, 65 (2008).

25. A. King, J. Readman and J. Zhou, Anal. Chim. Acta, 523, 259 (2004)

26. C. Li, H. Mi, W. Lee, W. You and Y. Wang, J. Hazard. Mater., 69, 1 (1999).

27. J. Pincemaille, C. Schummer, E. Heinen and G. Moris, Food Chem., 145, 807 (2014).

28. A. Escarrone, S. Caldas, E. Furlong, V. Meneghetti, C. Fagundes, J.L.O. Arias and E.G. Primel, Food Chem., 146, 597 (2014).

29. L. Yan, X. Li, J. Chen, X. Wang, J. Du and L. Ma, J. Environ. Sci. (China), 24, 116 (2012).
30. S. Shariati-Feizabadi, Y. Yamini and N. Bahramifar, Anal. Chim. Acta, 489, 21 (2003).

31. M.H. Hosseini, M. Rezaee, H.A. Mashayekhi, S. Akbarian, F. Mizani and M.R. Pourjavid, J. Chromatogr. A, 1265, 52 (2012).

32. M. Takino, S. Daishima, K. Yamaguchi and T. Nakahara, J. Chromatogr. A, 928, 53 (2001)

33. M. Ciecierska and M. Obiedzinski, Food Chem., 141, 1 (2013).

34. D. Essumang, D. Dodoo and J. Adjei, J. Food Compos. Anal., 27, 128 (2012).

35. M. Shen, R. Chapman, X. He, L. Liu, H. Lai, W. Chen and Q. Lan, Lung Cancer, 61, 275 (2008).

36. USEPA, US Environmental Protection Agency, Federal Register, 59 FR 1788 (1994).

37. F.H. Hussein, F.F. Karam and S.J. Baqir, Asian J. Chem., 26, 2781 (2014).

38. F.F. Karam, F.H. Hussein, S.J. Baqir and F.M. Abid, Asian J. Chem., 24, 5589 (2012).

39. D. Bright and N. Healey, J. Environ. Pollut., 126, 39 (2003).

40. C. Crépineau, G. Rychen, C. Feidt, Y. Le Roux, E. Lichtfouse and F. Laurent, J. Agric. Food Chem., 51, 4841 (2003).

41. H. Fromme, T. Lahrz, M. Piloty, H. Gebhardt, A. Oddoy and H. Ruden, Sci. Total Environ., 326, 143 (2004).

42. L.H. Lim, R.M. Harrison and S. Harrad, Environ. Sci. Technol., 33, 3538 (1999).

43. P.-J. Tsai, T.-S. Shih, S.-L. Chen, W.-J. Lee, G.-H. Lai and S.-H. Liou, Environ. Sci. Technol., 36, 4748 (2002). 